Düzeltme - Erratum

\title{
Bir Konut İçin Isıtma Konseptinin Termodinamik Analizi
}

\author{
Adem Avşar ${ }^{1 *}$, Oğuz Arslan²
}

Geliş / Received: 19/03/2020

Kabul / Accepted: 06/04/2020

\section{DÜZELTME}

Bilecik Şeyh Edebali Üniversitesi Fen Bilimleri Dergisinin 2020 yıll, 7. Cilt, 1. Sayısında yayınlanan "Bir Konut İ̧̧in Isıtma Konseptinin Termodinamik Analizi" başlıklı makalede yapılan düzeltme ve açıklamalar aşağıda sunulmuştur.

a. 82. Sayfada Giriş bölümünün ilk paragrafında yer alan "Makale değerlendirme ve kabul süreci hakkında ayrıntılı bilgiye dergi web sitesi üzerinden ulaşılabilir." şeklinde dergi şablonunda mevcut olan metnin makale üzerinde kaldığı fark edilmiş ve ilgili ifadenin silinmesi uygun görülmüştür.

b. Makaledeki Şekil numaraların birbirini takip edecek şekilde güncellenmesi uygun görülmüşür.

c. 87. Sayfada birinci paragraftan sonra "Farklı yakıt türleri kullanılması durumunda gerçekleşen ekserji kayıpları Şekil 6-7'de verilmektedir.” ifadesinin eklenmesi yazarlar tarafından uygun görülmüştür. 
Düzeltme - Erratum

\title{
Bir Konut İçin Isıtma Konseptinin Termodinamik Analizi
}

\author{
Adem Avşar ${ }^{*}$, Oğuz Arslan ${ }^{2}$
}

Geliş / Received: 19/03/2020

Kabul / Accepted: 06/04/2020

ÖZ

$\mathrm{Bu}$ çalışmada, örnek bir konut için ısıtma davranışı enerjitik ve ekserjitik açısından değerlendirilmiştir. Bu bağlamda, TS 825 (Binalarda 1sı yalıtım kuralları) açısından bir örnek konut için 1sı kayıpları ve kazanımları hesaplanmıştır. Bu bağlamda, ele alınan kontrol hacmi (örnek konut) için farklı parametreler dikkate alınarak enerji ve ekserji analizleri gerçekleştirilmiştir. Buna göre, en çok 1sı gereksinimi ocak ayında iç ortam sıcaklığının $24^{\circ} \mathrm{C}$ kabul edilmesi durumunda $5500 \mathrm{kWh}$ olarak, ekserji verimi ise \%3 olarak hesaplanmıştır.

1*Sorumlu yazar iletişim: ademavsr@gmail.com (https://orcid.org/0000-0002-8465-4081) Enerji Sistemleri Mühendisliği ABD, Lisansüstü Eğitim Enstitüsü, Bilecik Şeyh Edebali Üniversitesi 2İletişim: oguz.arslan@bilecik.edu.tr (https://orcid.org/0000-0001-8233-831X)

Makine Mühendisliği Bölümü, Bilecik Şeyh Edebali Üniversitesi, Mühendislik Fakültesi, Bilecik, Türkiye 


\title{
Thermodynamic Analysis of the Heating Concept for a Residence
}

\begin{abstract}
In this study, the thermal performance of a residence was evaluated in terms of energy and exergy. In this context, heat losses and gains were calculated for a sample residence taking the rules of TS 825 (thermal insulation rules in buildings) into account. Energy and exergy analysis were conducted for different parameters on the control volume (sample residence). In this regard, the maximum heat requirement during the heating period was calculated as approximately $5500 \mathrm{kWh}$ in January for indoor temperature of $24^{\circ} \mathrm{C}$ and the highest exergy efficiency was calculated as $3 \%$.
\end{abstract}

Keywords- Energy, Exergy, Heat loss, Residence 


\section{GİRIŞ}

Binalar yüksek oranda bir enerji kullanıcılarıdır. Binalarda hem mahallerin 1sıtılması için hem de sıcak su elde etmek için enerjiye ihtiyaç vardır. Binaların enerji ihtiyacını, yalıtımı artırarak veya bina kabuğunun hava sızıntısını azaltarak düşürmeye çalışılır. Binanın konumunu en iyi şekilde kullanmak ışınımla kazanımları arttırmak, enerji gereksinimini azaltacaktır. Buna bağlı olarak şehirlerin veya yapıların planlamaları yapılırken enerji kazançları ve kayıplarının değerlendirilmesi, binalarda kullanılacak enerji tüketiminin düşmesine sebep olacaktır.

Ekserji analizi yöntemi kullanılarak; bina ısıtma sistemlerinde daha yüksek verimler, fiyat, kaynak kullanımı, çevresel etki ve sürdürülebilirlik için yapılması gereken iyileştirmeler mümkün kılınabilir.

Düşük ekserji ihtiyaçları için uygun enerji kaynaklarının kullanımı konusundaki sistem tasarımlarına ek olarak, ekserji kayıplarını en aza indirgeyecek şekilde bina sistemi kontrol stratejilerinin belirlenmesi gereklidir. İyi bir yalıtım, bina kabuğundaki hava sızıntılarının önlenmesi, gün ışığından faydalanılması ve güneş enerjisinin pasif kullanımı önemli faktörlerdir.

Binaların 1sıtma sistemlerinin geleneksel enerji analiziyle beraber ekserji analizinde kullanılarak incelenmesi konusunda birçok çalışma bulunmaktadır. Schmidt [1] yaptığı çalışmada, ısı kayıplarını elde etmek için enerji ve ekserji analizlerine dayanan hesaplamalar yapmıştır. Birden çok ailenin yaşadığı bir binada, bina kabuğu için iyileştirmeler sağlamıştır. Duvar ve pencerelerin 1sı geçirgenlik katsayılarını değiştirerek odanın ekserji yükünü daha uygun bir değere indirgemiştir. Shukuya [2] ise binaların daha iyi bir şekilde değerlendirilebilmesi için ekserji yaklaşımını anlatmıştır. Geleceğin binalarında 1sıtma ve soğutma için düşük ekserjili sistemlerin uygun olacağını ifade etmiştir. Balta [3], bir düşük ekserjili ısıtma sisteminin enerji, ekserji, ekserji maliyet analizleri ile sürdürülebilirlik değerlendirmesini yapmıştır. $2366 \mathrm{~m}^{2}$ alana sahip kapalı bir spor salonunun ele alındığı örnek çalışma ile kazan, yoğuşmalı kazan ve hava kaynaklı 1sı pompası kullanan üç farklı 1sıtma sistemini araştırmıştır. Han ve arkadaşları [4], ekserji analizini bir binanın ısı yükü ve ilgili enerji akımlarını inceleyerek bina tasarımının iyileştirilme potansiyeli ve ekserji kayıplarının belirlenmesi üzerinde çalışmışlardır. Çin'de farklı iklim bölgelerinde yer alan beş farklı bina incelenmiştir.

$\mathrm{Bu}$ çalışmada, konutu temsil etmek üzere ele alınan bir kontrol hacmi (KH) ele alınmış ve bina ısıtma prosesi kapsamında enerji ve ekserji analizi metotlarıyla termodinamik açıdan değerlendirilmiştir.

\section{MATERYAL ve METOD}

Bina 1sıtma prosesinin termodinamik açıdan değerlendirilebilmesi için ele alınan KH Şekil 1'de verilmektedir.

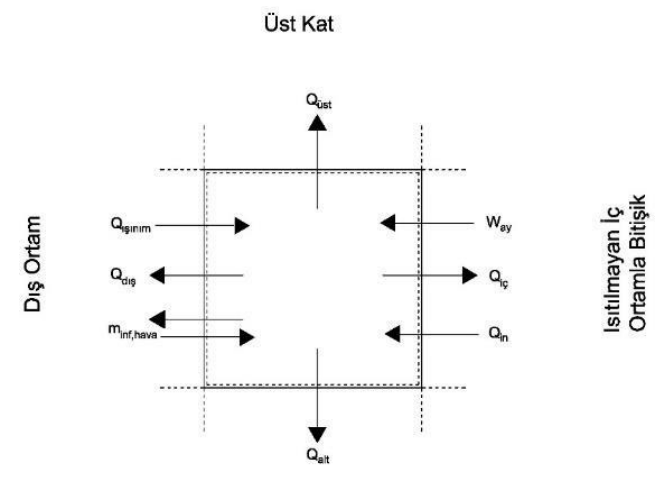

Alt Kat

Şekil 1. Isıtma prosesi Kontrol Hacmi. 
Şekil 1'de verilen KH hacmi taban alanı $330 \mathrm{~m}^{2}$, pencere alanı $22.76 \mathrm{~m}^{2}$, vehacmi $414 \mathrm{~m}^{3}$ olan bir konutu temsil etmektedir. Ele alınan KH'de, üst ve alt katta ısıtma yapılıp yapılmamasına bağlı olarak gerçekleşen 1sı kayıpları; dış duvar kabuğundan, tavan, taban ve ısıtılmayan iç ortamla bitişik duvar kabuğundan gerçekleşmektedir. Buna göre farklı iç ortam sıcaklıkları $\left(T_{i}\right)$, faklı 1sıtılmayan iç ortam sıcaklıkları $\left(T_{1, \text { iç }}\right)$ alt ve üst katta ısıtma yapılıp yapılmaması durumları için parametreler oluşturulmuş ve bu parametreler ışığında farklı 1sıtma sistemleri ve farklı yakıt kullanım durumları ele alınmıştır. Oluşturulan parametrelere bağlı örnek çalışma koşulları Tablo1'de verilmektedir.

Tablo 1. Yapı bileşenleri detayları.

\begin{tabular}{lc}
\hline Yapı bileşeni & Isı iletim katsayısı,(W/m K) \\
\hline Dış duvar (Dış havaya açık) & 0.395 \\
Kolon Kiriş (Dış havaya açık) & 0.499 \\
İç duvar (ısıtılmayan ortama bitişik,20cm) & 0.52 \\
Dış pencere & 1.3 \\
Dış kapı & 3.5 \\
Ara kat Döşemesi(rabıta) & 0.561 \\
Çatı & 0.369 \\
Açık Geçit Taban(rabıta) & 0.568 \\
Açık Geçit Taban (toprak temaslı) & 0.332 \\
\hline
\end{tabular}

Şekil 1'de verilen KH'ne göre kütlenin korunumu ifadesi;

$$
\sum m_{g}=\sum m_{\zeta}
$$

şeklindedir. Ele alınan $\mathrm{KH}$ için enerji dengesi ise;

$$
\sum E_{g}-\sum E_{\zeta}=\Delta E_{s i s}
$$

şeklinde verilir. Bir ısıtma sezonu için bu ifade;

$$
\sum E_{g}-\sum E_{\zeta}=0
$$

şeklinde yazılabilir; Şekil 1'deverilen bileşenler doğrultusunda enerji denklemi;

$$
Q_{\text {gerekli }}=\left(Q_{\text {lşınmm }}+Q_{\text {cihaz }}+Q_{\text {insan }}+Q_{\text {inf }, g}\right)-\left(Q_{\text {duvar }}+Q_{\text {ïst }}+Q_{\text {alt }}+Q_{i c ̧}+Q_{i n f, \zeta}\right)
$$

şeklinde ifade edilebilir. Burada $Q_{a l t}$; tabandan kaybolan 1Sı, $Q_{\text {üst }}$; tavandan kaybolan 1S1, $Q_{i c ̧} ;$ 1sıtılmayan iç ortamla bitişik duvardan kaybolan 1sı, $Q_{\text {duvar }}$; dış ortama bakan duvar kabuğundan kaybolan 1 ș,$Q_{\text {inf,g }}$; diş ortamdan iç ortama sızan havadan kaynaklanan 1 sı, $Q_{\text {inf,ç; }}$ iç ortamdan dış ortama sızan havadan kaynaklanan 1sı $Q_{\text {ışııım; }}$ güneş ışınlarından kazanılan 1Sı, $Q_{\text {cihaz }}$; cihazların enerji transferi ile kazanılan 1sı, $Q_{\text {insan }}$; insanların metabolik faaliyetlerinden kazanılan ısı enerjisi tanımlanmış olup aşağıdaki verildiği gibi tanımlanmıştır [5].

$$
\begin{aligned}
& Q_{\text {duvar }}=A_{\text {duvar }} \cdot U_{\text {duvar }} . \Delta t \\
& Q_{\text {üst }}=A_{\text {tavan }} \cdot U_{\text {tavan }} \cdot \Delta t \\
& Q_{\text {alt }}=A_{\text {taban }} \cdot U_{\text {taban }} \cdot \Delta t \\
& Q_{i c ̧}=A_{\text {ic,duvar }} \cdot U_{\text {ic,duvar }} \cdot \Delta t
\end{aligned}
$$




$$
\begin{aligned}
& Q_{\text {işınm }}=\sum r i_{\text {ay }} \cdot g i_{\text {ay }} \cdot I i_{\text {ay }} \cdot A_{i} \\
& Q_{\text {inf }, g}=0,33 \cdot n_{h} \cdot V_{h \cdot} \cdot T_{i} \\
& Q_{\text {inf }, c}=0,33 \cdot n_{h} \cdot V_{h \cdot} \cdot T_{d} \\
& Q_{\text {insan }}=W_{\text {insan }} \\
& Q_{\text {aydinlatma }}=W_{\text {aydinlatma }}
\end{aligned}
$$

Buna göre gerekli yakıt miktarı;

$$
m_{\text {yaklt }}=\frac{Q_{\text {gerekli }}}{\eta_{\text {yakmasistemi }} \cdot H_{u}}
$$

ifadesi ile bulunur.

Ele alınan $\mathrm{KH}$ için ekserji dengesi ise;

$$
E x_{g}-E x_{c}-E x_{d}=\Delta E_{X}
$$

şeklinde verilir. Bir ısıtma periyodu için;

$$
E x_{d}=E x_{g}-E x_{\varsigma}
$$

şeklinde tekrar yazılabilir. Şekil 1'de verilen bileşenler doğrultusunda;

$$
E x_{d}=\left(E x_{\text {lşnum }}+E x_{\text {cihaz }}^{w}+E x_{\text {insan }}^{Q}+E x_{i n f, g}+E_{X} \underset{\text { yaktt }}{ }\right)-\left(\operatorname{xx}_{\text {duvar }}^{Q}+E x_{\text {usst }}^{Q}+E x_{\text {alt }}^{Q}+E x^{Q}+\right.
$$

$E x_{i n f, \zeta)}$

eşitliği elde edilir. Burada;

$$
\begin{aligned}
& { }_{\text {duvar }}=\left(1-\frac{T_{0}}{T}\right) \cdot Q_{\text {duvar }} \\
& { }_{\text {alt }}^{E Q^{Q}}=\left(1-\frac{T_{0}}{T}\right) \cdot Q_{\text {alt }} \\
& \text { ux }^{Q} s t=\left(1-\frac{T_{0}}{T}\right) \cdot Q_{\text {üst }} \\
& E x_{i c ̧}^{Q}=\left(1-\frac{T_{0}}{T}\right) \cdot Q_{\text {iç }} \\
& E x_{\text {lşınım }}=\left(1+\frac{1}{3} \cdot\left(\frac{T_{0}}{T}\right)^{4}-\frac{4}{3} \cdot \frac{T_{0}}{T}\right) \cdot I_{\text {ş̧ınım }}
\end{aligned}
$$

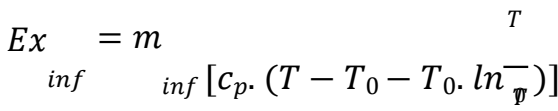

$$
\begin{aligned}
& E x_{\text {cihaz }}^{w}=W_{\text {cihaz }} \\
& { }_{\text {insan }}^{\text {ExQ }}=\left(1-\frac{T_{0}}{T}\right) \cdot Q_{\text {insan }}
\end{aligned}
$$

olup, ekserji verimi; 


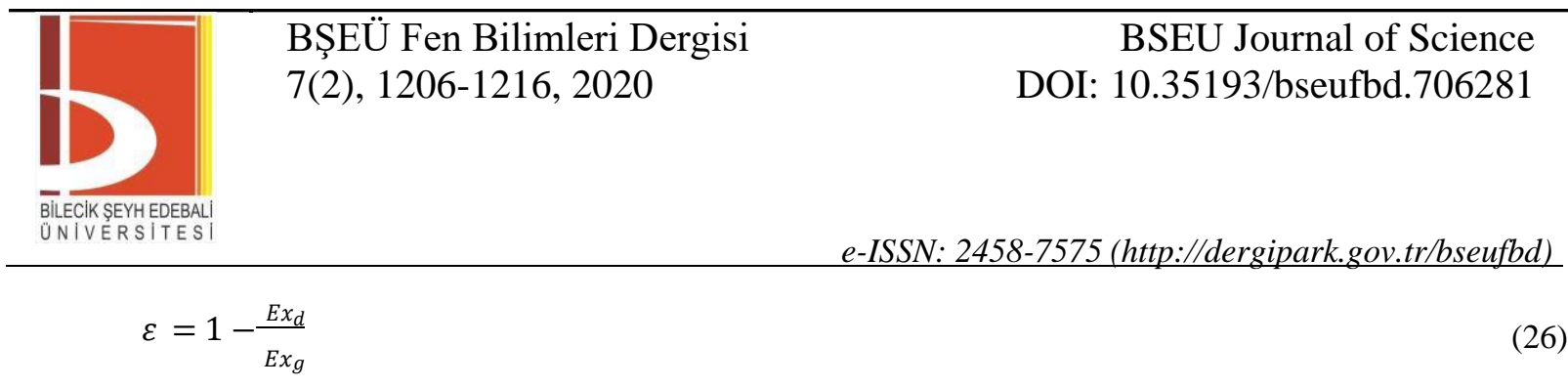

şeklinde verilir.

\section{BULGULAR VE TARTIŞMA}

Enerji ve ekserji analizi için gerekli parametreler Tablo 2'de verildiği şekliyle hesaplara dâhil edilmiştir.

Tablo 2. Hesap parametreleri [5,6]

\begin{tabular}{|c|c|c|}
\hline Semboller & Açıklama & Değerler \\
\hline $\mathrm{r}_{\mathrm{i}, \mathrm{ay}}$ & Saydam yüzeylerin aylık ortalama gölgelenme faktörü & 0.6 \\
\hline$g_{\mathrm{i}}$ & $\begin{array}{l}\text { Laboratuar şartlarında ölçülen ve yüzeyde dik gelen ışın için } \\
\text { güneş enerjisi geçirme faktörü }\end{array}$ & 0.75 \\
\hline $\mathrm{T}_{\mathrm{i}}\left({ }^{\circ} \mathrm{C}\right)$ & İç ortam sıcaklığı için parametreler & $18-24$ \\
\hline $\mathrm{T}_{\mathrm{iç}}$ & Isıtılmayan iç ortam sıcaklığı için parametreler & $0-15$ \\
\hline \multirow{6}{*}{$\mathrm{T}_{\mathrm{d}}-\mathrm{Q}_{1 ঙ ̣ ! m m}$} & Ekim & $14.1^{\circ} \mathrm{C}-700.03 \mathrm{~W}$ \\
\hline & Kasım & $8.5^{\circ} \mathrm{C}-495.72 \mathrm{~W}$ \\
\hline & Aralık & $3.8^{\circ} \mathrm{C}-435.22 \mathrm{~W}$ \\
\hline & Ocak & $2.9^{\circ} \mathrm{C}-505.39 \mathrm{~W}$ \\
\hline & Şubat & $4.4^{\circ} \mathrm{C}-671.38 \mathrm{~W}$ \\
\hline & Mart & $7.3^{\circ} \mathrm{C}-881.83 \mathrm{~W}$ \\
\hline$\eta_{\text {yak.sis., doğalgaz }}$ & Doğalgaz kazanı, yakma sisteminin verimi & 0.885 \\
\hline$\eta_{\text {yak.sis,kömür }}$ & Kömür kazanı, yakma sisteminin verimi & 0.772 \\
\hline$\eta_{\text {kömür,kazan }}$ & Kazan verimi & 0.772 \\
\hline$\eta_{\text {dogalgaz,kazan }}$ & Kazan verimi & 0.885 \\
\hline $\mathrm{W}_{\text {aydınlatma }}$ & Cihazlardan gelen enerji KH için & $102 \mathrm{~W}$ \\
\hline $\mathrm{W}_{\text {insan }}$ & İnsanlardan gelen enerji $\mathrm{KH}$ için & $464 \mathrm{~W}$ \\
\hline $\mathrm{n}_{\mathrm{h}}$ & Doğal havalandırma kat sayısı (TS825) & 0.8 \\
\hline $\mathrm{V}_{\mathrm{h}}$ & KH'nin hacmi & $414 \mathrm{~m}^{3}$ \\
\hline
\end{tabular}

Enerji analizi sonuçlarına göre; gerekli ısı enerjisi değerlerinin değişimi, 1sıtılmayan iç ortam, KH sıcaklık parametreleri ve aylara bağlı olarak Şekil 2-5'te verilmektedir.

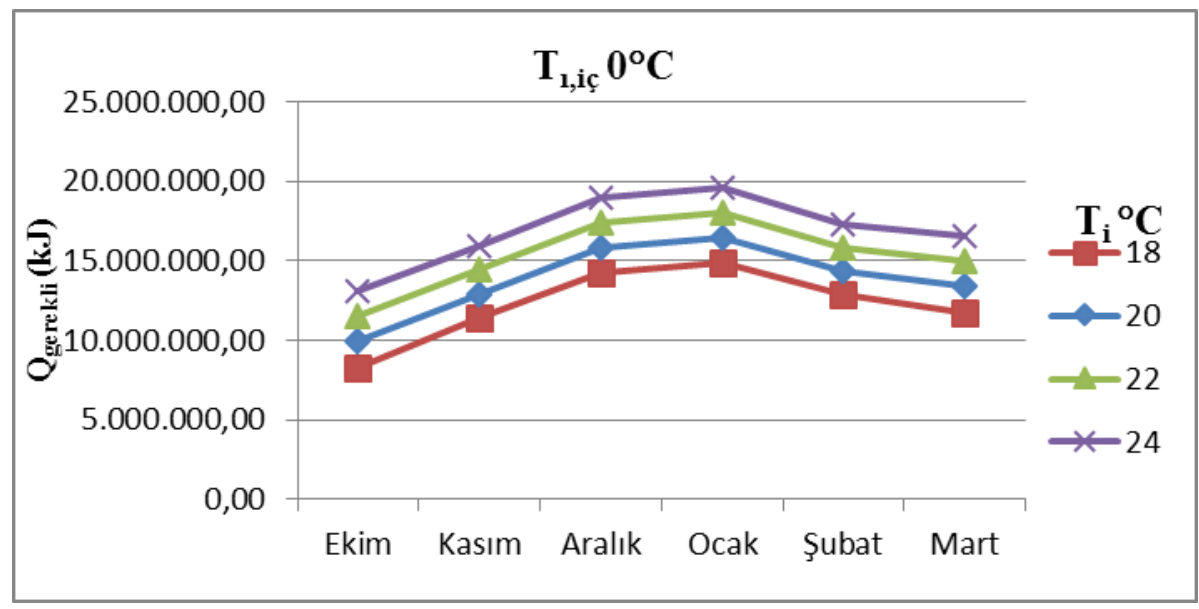

Şekil 2. Isıtılmayan ortam sıcaklığının $0^{\circ} \mathrm{C}$ durumunda 1sı gereksinimlerinin değişimi. 
Şekil 2 incelendiğinde, 1sıtma ihtiyacı için gerekli ısı enerjisi değerleri 8311160.46 kJ $-19633091.10 \mathrm{~kJ}$ arasında değişmektedir. İç ortam tasarım sıcaklığı arttığında beklenildiği gibi ısı gereksinimleri de artmaktadır. En yüksek ısı gereksinimi iç ortam sıcaklığının $24^{\circ} \mathrm{C}$ olması durumunda Aralık-Ocak aylarında belirlenmiştir.

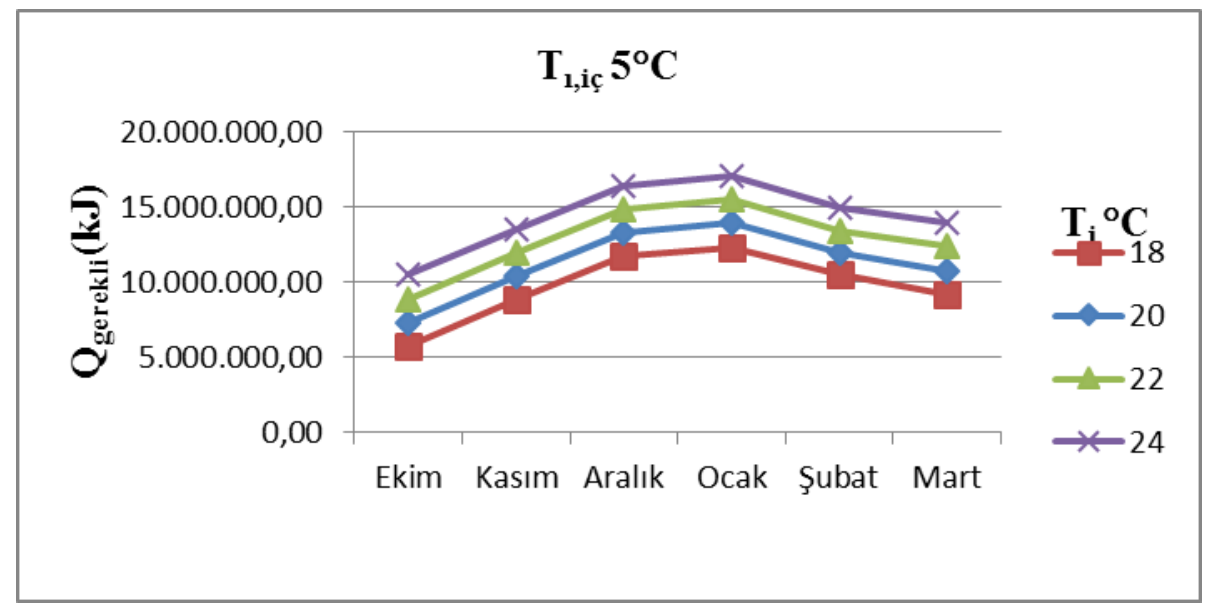

Şekil 3. Isıtılmayan ortam sıcaklığının $5^{\circ} \mathrm{C}$ durumunda 1 sı gereksinimlerinin değişimi.

Şekil 3 incelendiğinde, ısıtma ihtiyacı için gerekli ısı enerjisi değerleri $5739323.07 \mathrm{~kJ}-17061253.71 \mathrm{~kJ}$ arasında değişmektedir. İç ortam tasarım sıcaklığı arttığında beklenildiği gibi 1sı gereksinimleri de artmaktadır. En yüksek ısı gereksinimi iç ortam sıcaklığının $24{ }^{\circ}$ Colması durumunda Aralık-Ocak aylarında belirlenmiştir.

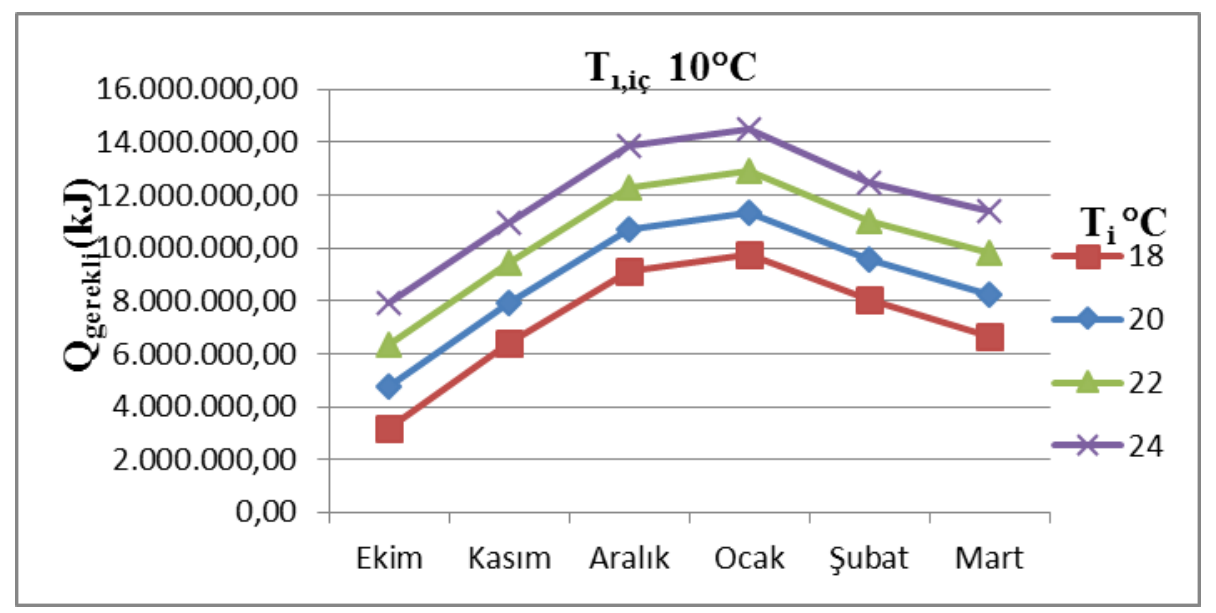

Şekil 4. Isıtılmayan ortam sıcaklığının $10^{\circ} \mathrm{C}$ durumunda 1 sı gereksinimlerinin değişimi.

Şekil 4 incelendiğinde, 1sıtma ihtiyacı için gerekli 1sı enerjisi değerleri 3167485.68 kJ $-14489416.31 \mathrm{~kJ}$ arasında değişmektedir. İç ortam tasarım sıcaklığı arttığında beklenildiği gibi 1sı gereksinimleri de artmaktadır. En yüksek ısı gereksinimi iç ortam sıcaklığının $24^{\circ} \mathrm{C}$ olması durumunda Aralık-Ocak aylarında belirlenmiştir. 


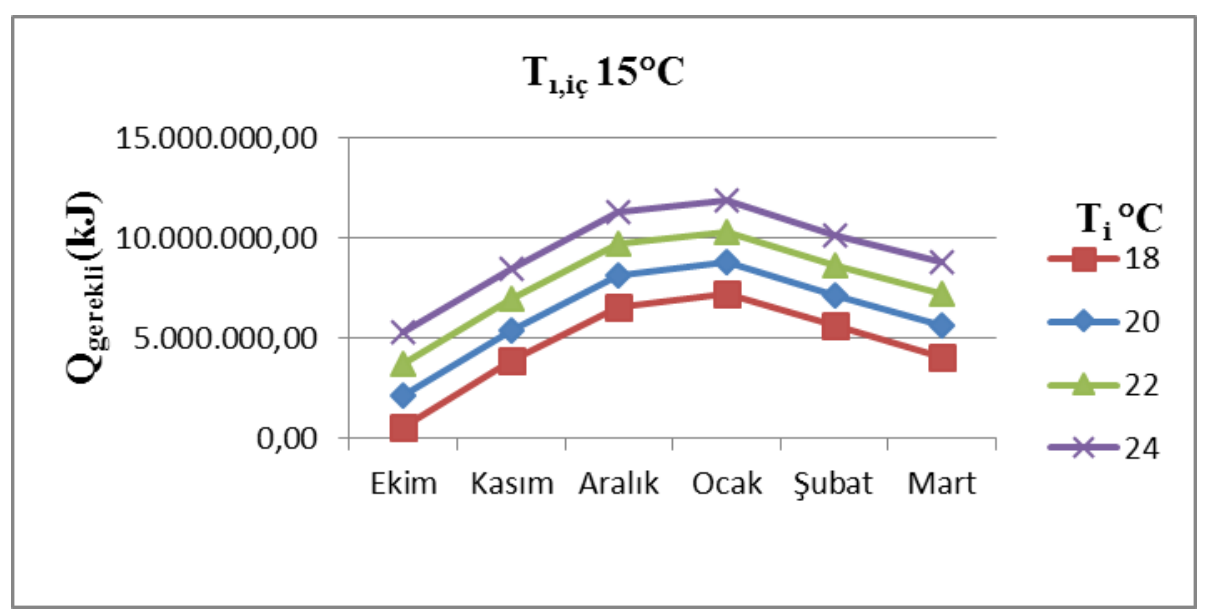

Şekil 5. Isıtılmayan ortam sıcaklığının $15^{\circ} \mathrm{C}$ durumunda ısı gereksinimlerinin değiş̧imi.

Şekil 5 incelendiğinde, 1sıtma ihtiyacı için gerekli 1sı enerjisi değerleri $595648.29 \mathrm{~kJ}-11917578.92 \mathrm{~kJ}$ arasında değişmektedir. İç ortam tasarım sıcaklığı arttığında beklenildiği gibi 1sı gereksinimleri de artmaktadır. En yüksek 1sı gereksinimi iç ortam sıcaklığının $24^{\circ} \mathrm{C}$ olması durumunda Aralık-Ocak aylarında belirlenmiştir.

Farklı yakıt türleri kullanılması durumunda gerçekleşen ekserji kayıpları Şekil 6-7'de verilmektedir.

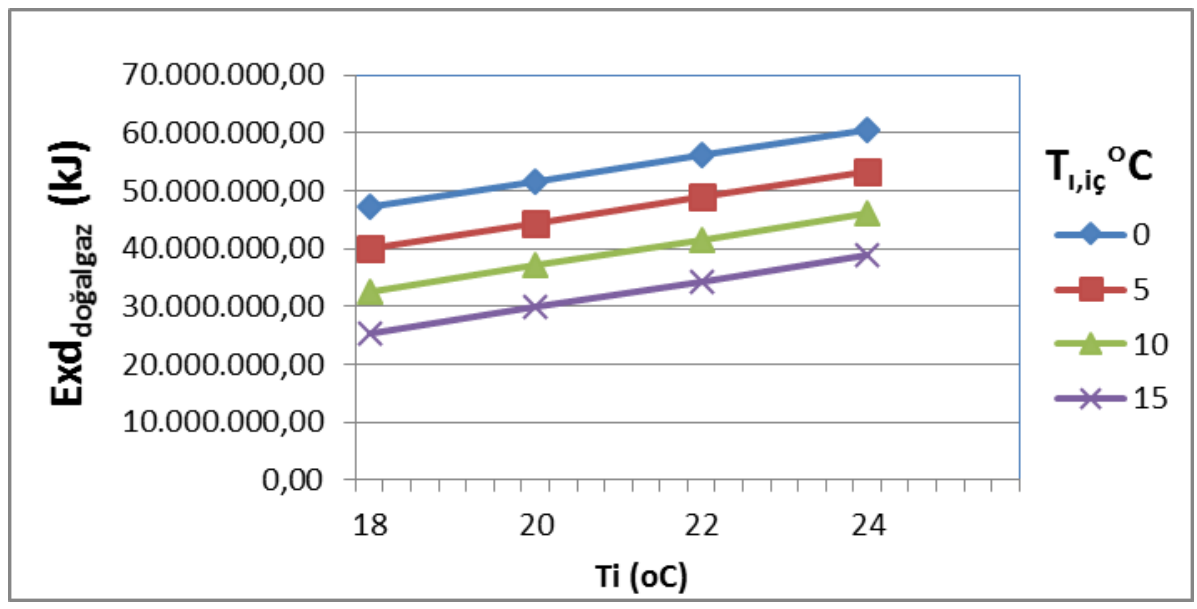

Şekil 6. Doğalgaz kullanılması durumunda ekserji kayıpları

Şekil 6 incelendiğinde, yakıt olarak doğalgaz kullanılması durumu için KH sıcaklık parametrelerine $\left(\mathrm{T}_{\mathrm{i}}{ }^{\circ} \mathrm{C}\right)$ bağlı olarak, ısıtılmayan iç ortam sıcaklık değeri düştügünde yıkımın daha fazla gerçekleştiği görülmüştür. 


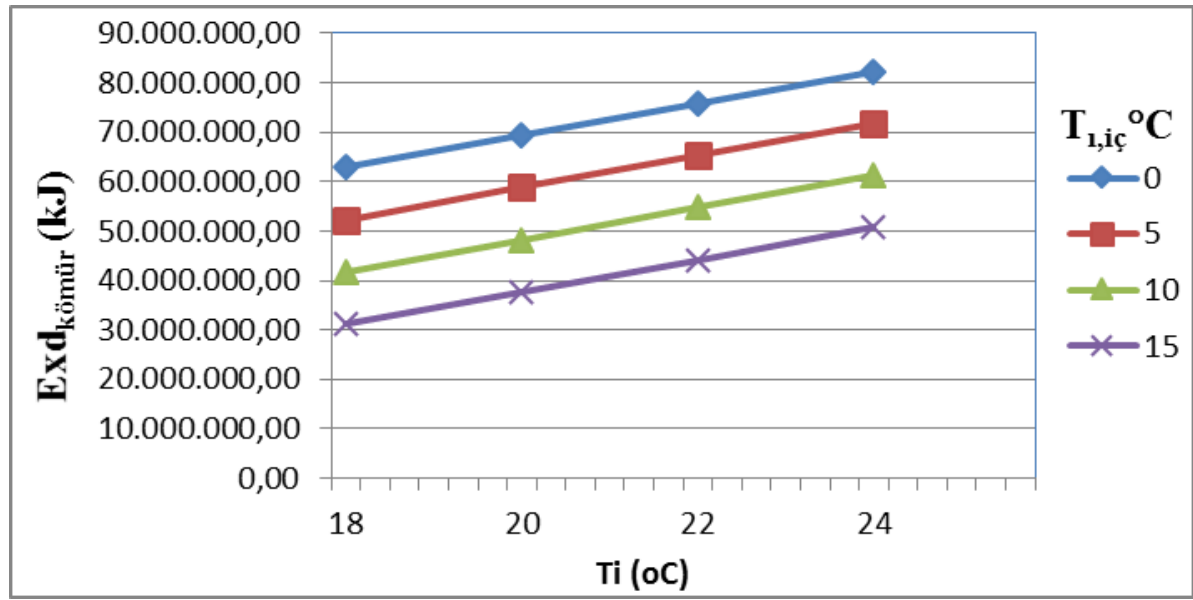

Şekil 7. Kömür kullanılması durumunda ekserji kayıpları

Şekil 7 incelendiğinde, yakıt olarak kömür kullanılması durumu için $\mathrm{KH}$ sıcaklık parametrelerine $\left(\mathrm{T}_{\mathrm{i}}{ }^{\circ} \mathrm{C}\right)$ bağlı olarak, 1sıtılmayan iç ortam sıcaklık değeri düştüğünde yıkımın daha fazla gerçekleştiği görülmüştür. Ekserji verim değişimleri Şekil 8-9'da verildiği gibidir.

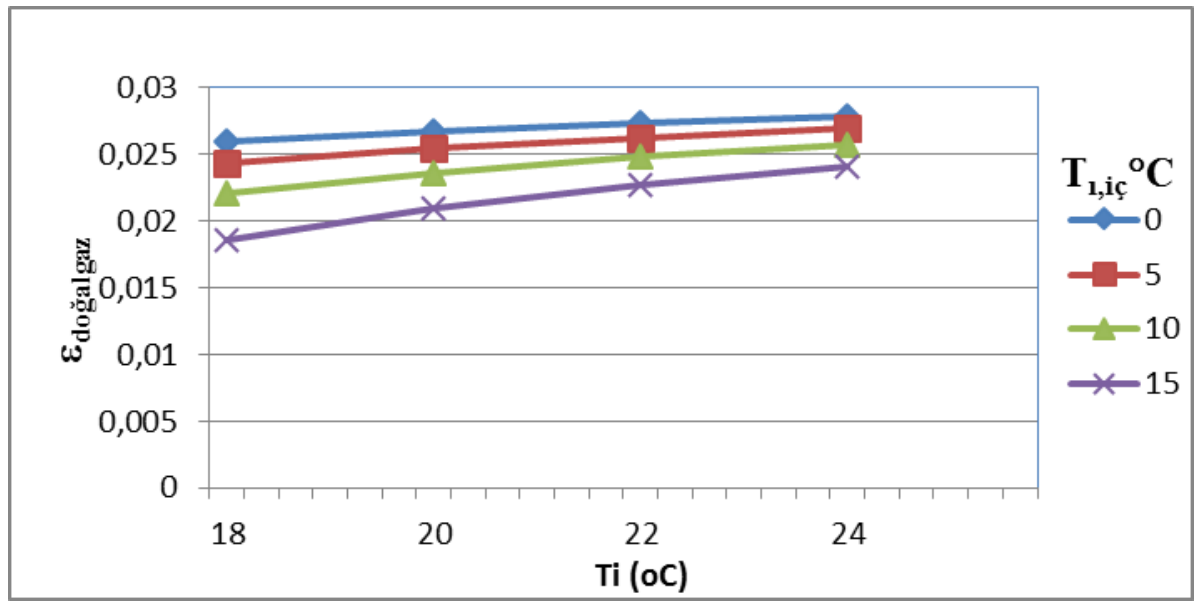

Şekil 8. Doğalgaz kullanılması durumunda ekserji verimliliğ

Şekil 8 Doğal gaz yakıt olarak kullanılması durumunda HK sıcaklık parametrelerine bağlı olarak, $\mathrm{T}_{1, \text { iç }} 0^{\circ}$ $\mathrm{C}$ ve $\mathrm{T}_{\mathrm{i}} 24^{\circ} \mathrm{C}$ durumunda en yüksek verim 0.028 olarak hesaplanırken, en düşük verim ise sıcaklık parametreleri $\mathrm{T}_{1, \text { iç }} 15^{\circ} \mathrm{C}$ ve $\mathrm{T}_{\mathrm{i}} 18^{\circ} \mathrm{C}$ durumunda 0.019 olarak hesaplanmıştır. Elde edilen verilere göre ise ekserji verimliliği oldukça düşük bulunmuştur. 

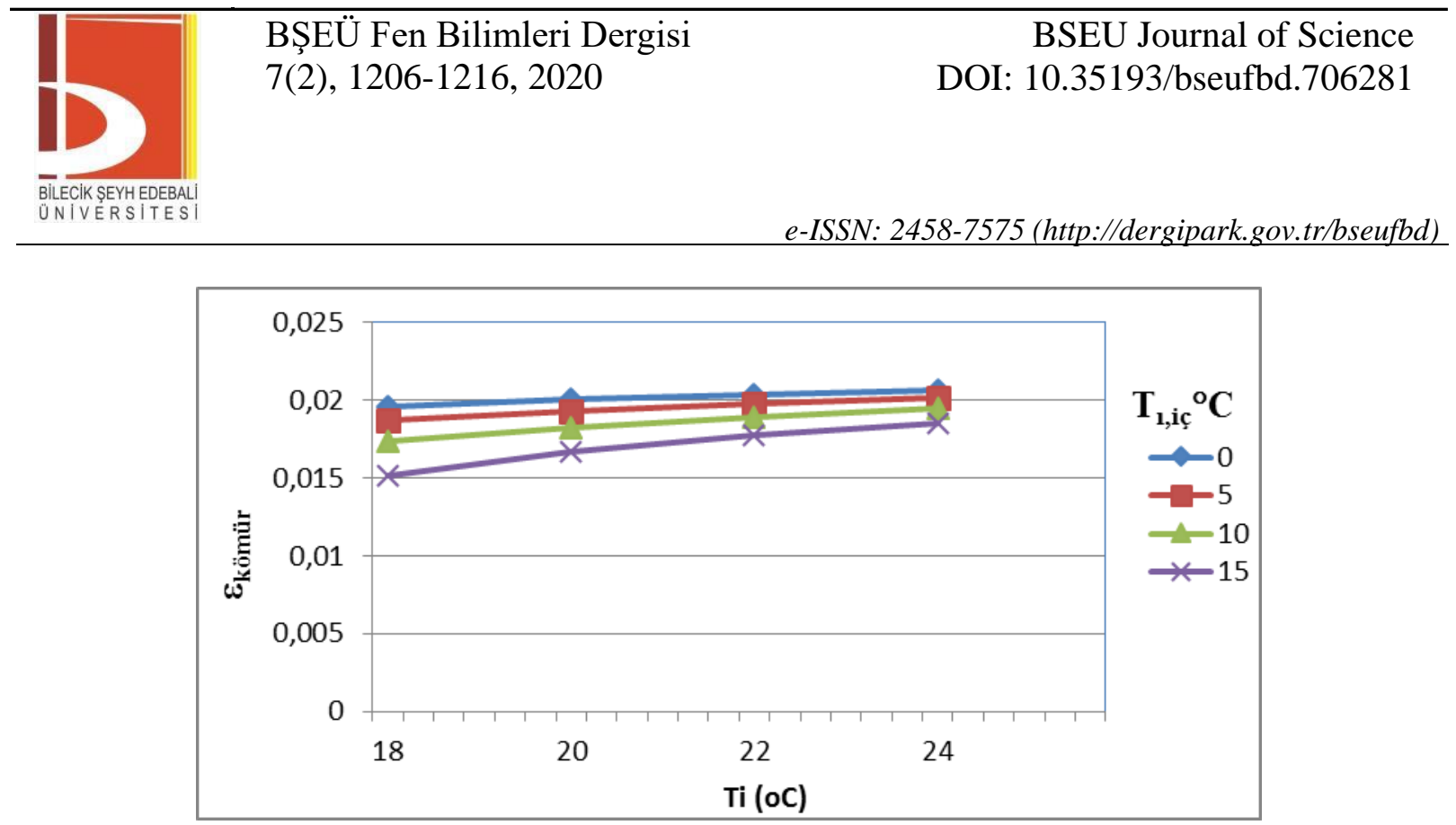

Şekil 9. Kömür kullanılması durumunda ekserji verimliliği

Şekil 9 kömür yakıt olarak kullanılması durumunda KH sıcaklık parametrelerine bağlı olarak, $\mathrm{T}_{1, \text { iç }} 0^{\circ} \mathrm{C}$ ve $\mathrm{T}_{\mathrm{i}} 24{ }^{\circ} \mathrm{C}$ durumunda en yüksek verim 0.021 olarak hesaplanırken, en düşük verim ise sıcaklık parametreleri $\mathrm{T}_{1, i \mathrm{c}} 15^{\circ} \mathrm{C}$ ve $\mathrm{T}_{\mathrm{i}} 18^{\circ} \mathrm{C}$ durumunda 0.015 olarak hesaplanmıștır. Elde edilen verilere göre ise ekserji verimliliğgi oldukça düşük bulunmuştur.

\section{SONUÇLAR}

Yakıt olarak doğalgaz kullanılması durumda ekserji yıkımı değerleri azalmaktadır. Sistemin farklı yakıtlar kullanılması durumda ekserji verimi aynı koşullar baz alındığında, $\mathrm{KH}$ 'nin $24^{\circ} \mathrm{C}$ olması ve ssıtılmayan ortam sıcaklı̆̆ının $0^{\circ} \mathrm{C}$ olması durumunda Exddoğalgaz'ın en yüksek değeri 60570451.46(kJ) ile Exdkömür'ün en yüksek değeri 82174366.91(kJ) için kıyaslandığında, yaklaşık olarak \%26'lık ekserji yıkımında düşüş meydana gelmiştir.

KH'nin $18^{\circ} \mathrm{C}$ olması ve 1sıtılmayan ortam sıcaklığının $15^{\circ} \mathrm{C}$ olması durumunda Exddoğalgaz'ın en düşük değeri 25376917.93(kJ) ile Exdkömür'ün en düşük değeri 31324454.91(kJ) için kıyaslandığında, yaklaşık olarak \%19'luk ekserji yıkımında düşüş meydana gelmiştir.

Buna bağlı olarak 1sı gereksinimi arttığında doğalgaz kullanımı ekserji verimliliği açısından daha verimlidir. Ekserji verimliliği, yakıt olarak doğalgaz kullanılması durumunda ve tüm parametreler göz önüne alındığında 0.018598869-0.027845905 arasında ve yakıt olarak kömür kullanılması durumunda ve tüm parametreler göz önüne alındığında 0.015120921-0.020676492 arasında çıkmıştır. Bu parametrelerde; KH'nin $24^{\circ} \mathrm{C}$ olması ve 1 sıtılmayan ortamın $0^{\circ} \mathrm{C}$ olması durumunda verimliliğin en yüksek değere, $\mathrm{KH}$ 'nin $18^{\circ} \mathrm{C}$ olması ve 1sitılmayan ortamın $15^{\circ} \mathrm{C}$ olması durumunda verimliliğin en düşük değere sahip olduğu görülmektedir. Buna rağmen ekserji verimleri oldukça düşüktür. Bunu sebebi atık 1sılardan fayda sağlanamaması, enerjinin 1sı enerji olarak kullanılmasından kaynaklanmaktır. Ekserji artırımı yapmak için yanma sonun atıklarının değerlendirilmesi düșünülebilir.

\section{KAYNAKLAR}

[1] Schmidt, D. (2004). Design of low exergy buildings-method and a pre-design tool. The International Journal of Low Energy and Sustainable Buildings, 3(2004), 1-47.

[2] Shukuya, M. (2009). Exergy concept and its application to the built environment. Building and Environment, 44(7), 1545-1550.

[3] Balta, M. T., Kalinci, Y., \& Hepbasli, A. (2008). Evaluating a low exergy heating system from the power plant through the heat pump to the building envelope. Energy and Buildings, 40(10), 1799-1804. 
[4] Han, T., Zheng, Y., \& Gong, G. (2017). Exergy analysis of building thermal load and related energy flows in buildings. Indoor and Built Environment, 26(9), 1257-1273.

[5] TSE (Türk Standartları Enstitüsü), 2013. TS 825:Binalarda Isı Yalıtım Kuralları.

[6] Arslan, O., Ozgur, M. A., Yildizay, H. D., \& Kose, R. (2009). Fuel effects on optimum insulation thickness: an exergitic approach. Energy Sources, Part A: Recovery, Utilization, and Environmental Effects, 32(2), 128147.

[7] Hepbasli, A. (2008). A key review on exergetic analysis and assessment of renewable energy resources for a sustainable future. Renewable and sustainable energy reviews, 12(3), 593-661.

[8] Yücer, C. T. (2016). Ekserji Analizi Yöntemi Kullanilarak Bina Isıtma Sistemlerinin İncelenmesi. Mühendis ve Makina, 57(681), 59-64.

[9] Termodinamik.info. Doğalgaz Yakitlı Kazanlar. https://www.termodinamik.info/dogal-gaz-yakitli-kazanlar 